\title{
Islam and Iran's post-revolution war on drugs: a Durkheimian analysis
}

\author{
Zahra Farhadi Alashti ${ }^{1}$ \\ Ferdowsi University of Mashhad, Iran \\ E-mail:z.farhadialashti@mail.um.ac.ir
}

\author{
Abdolreza Javan Jafari Bojnordi ${ }^{2}$ \\ Ferdowsi University of Mashhad, Iran \\ E-mail: Javan-j@um.ac.ir \\ DOI:10.18326/ijims.v11i2.327-350
}

\begin{abstract}
Despite widespread criticism of the failure to achieve the predetermined penal and criminological goals of Iran's post-revolution war on drugs, the harsh penal practices remain in practice until today. By applying Durkheim's attitude in his last major work, the elementary forms of religious life, the purpose of this paper is to analyze the rationale for the Iranian war on drugs from the perspective of religion and not penal code or criminology. This article draws on qualitative analysis, and data were collected through analysis of legal documents, literature discussing the war on drugs,

${ }^{1} \mathrm{Ph} . \mathrm{D}$. Student in Criminal Law and Criminology at Department of Criminal Law and Criminology, Faculty of Law and Political Sciences, Ferdowsi University of Mashhad, Azadi Square, Mashhad, Razavi Khorasan Province, Iran. E-mail: z.farhadialashti@mail.um.ac.ir.

${ }^{2}$ Corresponding Author: Abdolreza Javan Jafari Bojnordi, Associate Professor of Sociology of Punishment at Department of Criminal Law and Criminology, Faculty of Law and Political Sciences, Ferdowsi University of Mashhad, Azadi Square, Mashhad, Razavi Khorasan Province, Iran. E-mail: Javan-j@um.ac.ir
\end{abstract}


news reports, and past journals. The findings of this article reveal that the war on drugs originates from an understanding that attributes evilness to such criminals to prevent the disintegration of Islamic society. This approach blurs the line between "preserving Islam" and the "Islamic society," and the repressive policies are consecrated to avoid social disintegration. Our study confirms Durkheim's attitude in which sacredness is highly contagious. Following the sanctity of preserving Islamic society from the profanity of drug crimes, the application of specialized mechanisms for fighting drugs, such as anticipating specialized criminal courts for violation of sacred values, setting special legislative authorities for the crime, and meting out harsh punishments, have all become plausible. Accordingly, all these practices would be treated as sacred because they are associated with fighting the "profane" phenomenon of drugs.

Terlepas dari kritik luas atas kegagalan untuk mencapai tujuan pidana dan kriminologis yang telah ditentukan sebelumnya dari perang pasca-revolusi Iran terhadap narkoba, praktik hukuman yang keras tetap ada hingga hari ini. Dengan menerapkan sikap Durkheim dalam karya besar terakhirnya, bentuk-bentuk dasar kehidupan beragama, tujuan makalah ini adalah untuk menganalisis alasan perang Iran terhadap narkoba dari perspektif agama dan bukan hukum pidana atau kriminologi. Artikel ini mengacu pada analisis kualitatif, dan data dikumpulkan melalui analisis dokumen hukum, literatur yang membahas perang melawan narkoba, laporan berita, dan jurnal masa lalu. Temuan artikel ini mengungkapkan bahwa perang terhadap narkoba berawal dari pemahaman yang mengaitkan kejahatan dengan penjahat tersebut untuk mencegah disintegrasi masyarakat Islam. Pendekatan ini mengaburkan batas antara "melestarikan Islam" dan "masyarakat Islam", dan kebijakan represif disucikan untuk menghindari disintegrasi sosial. Studi kami menegaskan sikap Durkheim di mana kesucian sangat menular. Mengikuti kesucian dalam melestarikan masyarakat Islam dari profanitas kejahatan narkoba, penerapan mekanisme khusus untuk memerangi narkoba, seperti mengantisipasi pengadilan pidana khusus untuk pelanggaran nilai-nilai suci, menetapkan otoritas legislatif khusus untuk kejahatan, dan menjatuhkan hukuman yang keras, semua itu menjadi masuk akal. Dengan demikian, semua praktik ini akan diperlakukan sebagai sesuatu yang sakral karena dikaitkan dengan memerangi fenomena "profan" narkoba.

Keywords: Drugs; Emile Durkheim; Islam; Functionalism; Social Solidarity 


\section{Introduction}

As a reflection of the values dominating society, the criminal justice system is regarded as one of the manifestations where religiously motivated ideas impact on regulating social relations. So, despite the criticism leveled by positivists in recent decades against basing laws "on nonempirical notions or appeals to romantic or religious source" ${ }^{3}$ - towards the end of the twentieth century, legal sociologists such as Shah, ${ }^{4}$ Yilmaz, ${ }^{5}$ Menski ${ }^{6}$ studied religion as a social institution in the developing field of sociology of law on religion. Although a vast number of cases regarding the hard functionalism of religion in the criminal justice systems of Middle Eastern countries exist, the amount of sociological literature in this field is scarce. One of the blatant manifestations of the hard functionalism of religion in the Middle East was in Iran after the 1979 Revolution. Despite the vast number of studies about crimes of religious nature in post-revolutionary Iran in recent years, ${ }^{7}$ a limited number of research studies have traced the historical alteration of Islamification of society on non-religious crimes. So by adopting a historically oriented sociology of punishment, ${ }^{8}$ we try to examine the effect of the religious force on the evolution and development of the

${ }^{3}$ Jeffrey Standen, "Critical Legal Studies as an Anti-Positivist Phenomenon", Virginia Law Review, Volume 72, Number 5 (1986), 983-998.

${ }^{4}$ Prakash Shah, Legal Pluralism in Conflict: Coping with Cultural Diversity in Law, London: Routledge, 2005.

${ }^{5}$ Ihsan Yilmaz, Muslim Laws, Politics and Society in Modern Nation States: Dynamic Legal Pluralisms in England, Turkey and Pakistan, Aldershot: Ashgate, 2005.

${ }^{6}$ Werner Menski, Hindu Law: Beyond Tradition and Modernity, New Delhi: Oxford University Press, 2008.

${ }^{7}$ For instance: Atefeh Abbasi and Atieh Rangchitehrani, "A new Opinion at issuance and performance Hudud on children and adolescents", Islamic Law Research Journal, Volume 21, Number 5 (2020), 151-176; Seyyed Ebrahim Ghodsi and Ali Porzarrin, "Critical analysis of article 637 of Islamic criminal law", Journal of Humanities and Social Sciences, Volume 3, Number 9 (2003), 183-211; Fatemeh Tavakoli, et al., "Religious Foundations and the Principles of Criminalization of Blasphemy and the Challenges", Criminal Law Research, Volume 6, Number 2 (2015), 49-74.

${ }^{8}$ David Garland, "Sociological Perspectives on Punishment", Crime and Justice, Volume 14 (1991),115-165. 
Iranian war on drugs during the forty years of the Revolution, according to Durkheim's theory of the social origins of religion in the Elementary Forms of the Religious Life. ${ }^{9}$

A historical approach to the Islamization of the war on drugs will unearth the reason behind the harsh policies against drugs despite the failure in achieving the philosophical and criminological objectives. According to Iran's Secretary of Human Rights, 93\% of the cases of death penalty are related to the trafficking of drugs. ${ }^{10}$ Moreover, as stated by the head of the judiciary, those prisoners, either directly or indirectly related to drugs, constitute around $70 \%$ of the country's prisoners. ${ }^{11}$ From the philosophical or penological perspective, the strict policies implemented so far should be dismissed from consideration; or fundamental reforms should be put into practice. However, harsh policies have continued. This research regards penal practices as a social reality-on par with other social phenomena. The benefit of applying the sociological perspective is that we could realize how the social and historical forces profoundly impact our current circumstances. So it is necessary to trace the social role of phenomena - that is, punishment ${ }^{12}$ and religion. This study will examine the role of religion in Iran's war on drugs.

\section{The efficacy of religion in the war on drugs}

Studying the law as a social phenomenon has absorbed the attention of many scholars like Duguit, ${ }^{13}$ Serverin, ${ }^{14}$ Ehrlich and Ziegert, ${ }^{15}$ and

\footnotetext{
${ }^{9}$ Émile Durkheim, Elementary Forms of the Religious Life, New York: Free Press, 1995.

${ }^{10}$ Tasnimnews. Mohammad Javad Larijani: 93\% of executions in Iran are related to drugs / The death penalty should be limited to drug traffickers, 2016, Retrieved on July 10, 2020 at: www. tn.ai/1207613.

${ }^{11}$ IRNA. 70\% of prisoners' crimes are related to drugs, 2018, Retrieved on July 10, 2020 at: www. irna.ir/news/83097023/.

${ }^{12}$ Michel Foucault, Discipline and Punish, London: Penguin Books,1995.

${ }^{13}$ Léon Duguit, Les transformations du droit public, Paris: Armand Colin,1999.

${ }^{14}$ Évelyne Serverin, Sociologie du Droit, Paris: La Découverte, Repères, 2000.

${ }^{15}$ Eugene Ehrlich and Klaus A. Ziegert, Fundamental Principles of the Sociology of Law, New
} 
Timasheff. ${ }^{16}$ As the findings of their research indicate, the basis on which the legal rule rests was to be sought in the social conscience, social institution, normative reality, or social believes. For Durkheim, the legal system was a mirror that reflected collective values. Drawing on Durkheim's interpretation of the social function of religion, we will examine the efficacy of the socially-oriented reading of religion in how the criminal justice system of Iran encounters the phenomenon of drugs. This examination will be done at four levels: valuation, legislative authority, criminalization and penalization, and the special courts.

\section{Valuation}

Legal positivists, like Hart, consider law inevitably determined by social facts. ${ }^{17}$ In the case of this study, the reason behind the percolation of religion into the realm of war on drugs should be seen in the early years of the Revolution. Following the establishment of the Islamic State, the war on drugs, a socially-motivated matter, turned into a religious one. This war was designated in the light of Islamic arguments as Difa'-e Muqaddas (literally, "the holy defense") and Jihad Akbar ("the great Jihad"). These consecrations stem from, in Durkheim's words, "the contagiousness of the sacred." ${ }^{18}$ Many behaviors, he believed, are not sacred or profane per se. Instead, it is the people's religious valuation of these behaviors and attributing sacredness to them that would cause these behaviors to be enclosed in sacredness.

In this regard, the reason for the sanctity of war on drugs could be seeking in the theological ideals of the 1979 Revolution. According to article 3 of

\footnotetext{
York: Transaction Publications, 2001.

${ }^{16}$ Nicholas Sergeyevitch Timasheff, An Introduction to the Sociology of Law, New Brunswick: Transaction Publishers, 2002.

${ }^{17}$ Scott J. Shapiro, Legality, Cambridge: The Belknap Press of Harvard University Press, 2011,266.

${ }^{18}$ Émile Durkheim, Elementary Forms of the ..., 224.
} 
the Constitution, the Revolution set the Muslim state the task of "creating a suitable setting for the development of ethical virtues resting on faith [imān], fear of God [Taqwā], and fighting all epitomes of corruption and decadence." Islamic society is said to be the standard-bearer of the revival of, and is consecrated because of being associated with, Islamic values. Therefore, whatever would contribute to the preservation of Islamic society was sacred. From the very first days of the Revolution, the criminal justice system authorities thought of drug crimes, especially drug trafficking, as one of the reasons contributing to the disintegration of Islamic society.

Ayatollah Khomeini, Iran's politico-religious leader, assumed the war on drugs to be a "divine undertaking" in which "the survival of Islam" must be considered as the main task. ${ }^{19}$ For him, Islam was not an entity isolated from Islamic society. He thus regarded drug abuse as Harām or "religiously forbidden" and quitting addiction as a Wajib-i Shar'i or "an imperative dictated by sharia law." ${ }^{20}$ The current leader of the Islamic Republic, Ayatollah Khamenei, too, tries to raise awareness by introducing the "enemies' conspiracy" to instigate corruption in the society ${ }^{21}$ and to "subjugate Islam" through a variety of methods, especially drugs. ${ }^{22}$ Like his predecessor, he equals the survival of the Islamic society with that of Islam. The hard war of the Iranian authorities against the drug addiction is for Ayatollah of a religious nature so much so that he, drawing on the Islamic discourse, employed the expression "Jihad Akbar" for the campaign. ${ }^{23}$

\footnotetext{
${ }^{19}$ Seyyed Ruhollah Khomeini, Sahifeh-ye Imam, Vol 21, Tehran: Institute of Organizing and Publishing Imam Khomeini's Works, 2010, 428.

${ }^{20}$ Seyyed Ruhollah Khomeini, Sahifeh-ye Imam ..., 428.

${ }^{21}$ Farsi. Khamenei, Students meet with the Leader of the Revolution during the training week, 1991, Retrieved on July 10, 2020 at: https://farsi.khamenei.ir/news-content?id=547.

${ }^{22}$ Farsi. Khamenei, Message to the Great Hajj Congress, 2009, Retrieved on July 10, 2020 at: http://farsi.khamenei.ir/message-content?id=8436.

${ }^{23}$ Farsi. Khamenei, Statements on the occasion of the 19th anniversary of the death of Imam Khomeini, 2008 Retrieved on July 10, 2020 at: https://farsi.khamenei.ir/speechcontent?id=3463.
} 
They gave the war a sacred characteristic because jihad signifies making efforts together with self-sacrificing for God with one's life, wealth, and whatever in their possession to propagate or defend Islam.

The Iranian authorities only restated and reinforced the feelings of citizens. The arousal of religious sentiments in the collective consciousness may be sought in the deeply-entrenched martyrdom culture, or what Durkheim designates as altruistic suicide. ${ }^{24}$ According to the Drugs Control Headquarters, during the 1979-2018 period, 41,000 war-on-drug operations were performed, in the course of which 3,815 police officers were killed. ${ }^{25}$ The religious position of these agents, as one of those protecting community morals, is so privileged that those killed in the fight are called martyrs. Their funerals are symbolic rites for strengthening the religious values and unify individual consciousnesses with society for the war against drug traffickers. In the course of these rites, which are accompanied by military marches, as Durkheim argued, "[the] individual consciousnesses which are actually closed to one another ... come to express themselves"26 by repeating the religious slogans and condemning the traffickers and their supporters. "It is by shouting the same cry, saying the same words, and performing the same action regarding the same object that they arrive at and experience agreement." ${ }^{27}$ So the moral power of society was obviously felt, and moral and social sentiments of the people are thus through these rites strengthened and renewed. ${ }^{28}$

Following the sacredness of the war on drugs, religious reading makes inroads in the criminal justice system's policy against drugs. In the following

\footnotetext{
${ }^{24}$ Émile Durkheim, Suicide: A study in sociology. London: Taylor \& Francis, 2005,175.

${ }^{25}$ Tasnimnews, Statistics of martyrs of 40 years of war on drugs+separate tables, 2019, Retrieved on July 10, 2020 at: www.tn.ai/2126272.

${ }^{26}$ Émile Durkheim, Elementary Forms of the..., 231.

${ }^{27}$ Émile Durkheim, Elementary Forms of the..., 232.

${ }^{28}$ Malcolm Hamilton, The Sociology of Religion: Theoretical and Comparative Perspectives, 2nd ed., London,New York: Routledge, 2001,114.
} 
section, we will analyze the influence of the sacredness of the war on drugs on legislative authorities.

\section{Legislative authority}

Although theoretically, according to article 4 of the Constitution, laws should be based on Sharia rules, practically fusing religion and politics affects the delegation of legislative power to specific authorities. In this regard, the first manifestation of the function of religion may be found in the establishment of the Council of the Islamic Revolution by the decree of Wali-ye Faqih or "the guardian jurist." 29 One month before the Revolution, on January 12, 1979, Ayatollah Khomeini instructed the authorities to set up and maintain the Council before the establishment of permanent political bodies. The ayatollah did this on account of "the right bestowed by sharia and based on the vote of confidence of the majority of Iranian people [to him] to realize the Islamic goals of the nation." ${ }^{30}$

For analyzing the importance of the Wali-ye Faqih decree in legitimating the Council of the Islamic Revolution, it is essential to attend to the sacred place of him before collective consciousness. As Durkheim states, the leader as a force risen from the collective consciousness is that which embodies the desires and ideals of a group. ${ }^{31}$ Ayatollah Khomeini was religiously labeled for Iranians as Imam -whom the leadership of the Islamic society is granted through "God's command." So if we look from Durkheim's perspective, which opinion is eminently a social thing and is one source

\footnotetext{
${ }^{29}$ For more information about Wali-ye Faqih, refer to the Sudarnoto Abdul Hakim, "Islam and government: an analytical review on Khumayni's Kashf al-Asra>r and Wila>yat al-Fa>qih", Indonesian Journal of Islam and Muslim Societies, Volume 8, Number 1 (2018), 163-166.

${ }^{30}$ Seyyed Ruhollah Khomeini, Sahifeh-ye Imam, Vol 5, Tehran: Institute of Organizing and Publishing Imam Khomeini's Works, 1979, 426.

${ }^{31}$ Émile Durkheim, The Division of Labour in Society, London: Palgrave MacMillan Ltd, 1984, 104.
} 
of authority, ${ }^{32}$ the sanctity of high religious characteristics such as imam Khomeini validates the institutions and orders, what he refers to it as the moral authority. In this situation, the statements of the authority are conceived as holy orders and "leave no room for hesitation." 33

The other force mentioned above is the achievement of the Islamic goals: Ayatollah Khomeini used "Islamic," not "Islamic society" because he saw no differences between these terms. The post-revolutionary Iran was seeking to realize the ideals of Shia Islam, to achieve which it had to make use of particular institutions. The Council of the Islamic Revolution was established with this purpose in mind - to make the Islamic goals come true. Drugs were deemed one of the essential factors, possessing the capacity to disintegrate the newly founded Islamic society and to undermine the ideal of the Islamic society. The concerns of the members of the Council regarding reducing the spiritual and material damages of drugs for the citizens led it to act well before the establishment of the parliament. In doing so, it passed - five months after the Revolution - a stringent bill to intensify the punishments for drug crimes in a bid to achieve the Islamic goals. The anticipation of many death penalty sentences, confiscation of the properties and imprisonment, criminalization of addiction to drugs, and reduction of the punishable amount of drug are indicative of the role of drug crimes in obstructing the achievement of Islamic goals.

The second manifestation of the function of religion in choosing the legislative authority concerns the newly minted institution known as the Expediency Assembly. Following the dissolution of the Council of the Islamic Revolution, the Expediency Assembly became the sole authority for passing laws on drugs. This held up until 2017, when the parliament ratified the law to append an article to the drug law. The Expediency Assembly

\footnotetext{
${ }^{32}$ Émile Durkheim, Elementary Forms of the.. ., 210.

${ }^{33}$ Émile Durkheim, Elementary Forms of the.. ., 209.
} 
was established to decide the benefits of Islamic society and preventing its disintegration. ${ }^{34}$ The Expediency Assembly was thus granted authority to pass drug laws, despite Ayatollah Khomeini's explicit statement denying any legislative power. Instead of going through the time-consuming process of lawmaking, the assembly began lawmaking despite the legal regulations, with recourse to the rationale behind the establishment of the assembly, according to the Article 10 of the Constitution, "[the assembly should take action in] solving the problems of the system which are not soluble through ordinary methods." For the assembly members, drugs were of high gravity because it threats the foundations of Islamic society. Having laid the foundation for enacting anti-drug laws in the assembly, it passed, over time, three subsequent laws on drugs.

Durkheim argued that society's attitude towards social realities is reflected in criminalization and penalization. In the following section, we will thus try to find out: first, the consecrating dimensions of the war on drugs as reflected in the documents and criminal law; and second, the extent to which criminal law of this area corresponds to the collective consciousness.

\section{Criminalization and penalization}

Durkheim discusses the special role laws play in reflecting the dynamics of society. As he argued, laws reflex the type of social solidarity ${ }^{35}$, and the traces of social developments can be discovered by analyzing them. In other words, "the center of gravity of legal development [...] since time immemorial has not lain in the activity of state but in the society itself." ${ }^{36}$ In the early years of post-revolutionary Iran, drugs were considered to

\footnotetext{
${ }^{34}$ Seyyed Ruhollah Khomeini, Sahifeh-ye Imam, Vol 20, Tehran: Institute of Organizing and Publishing Imam Khomeini's Works, 1979, 446.

${ }^{35}$ Émile Durkheim, The Division of ..., 64.

${ }^{36}$ Eugene Ehrlich and Klaus A. Ziegert, Fundamental Principles of ..., 390.
} 
be a dangerous means that would undermine the Islamic values and disintegrate society. Drug crimes are not just crimes against an individual but against the society in its entirety. ${ }^{37}$ Under such circumstances, "society communicates that it is not going to tolerate this type of offense." ${ }^{38}$ The newly founded society, as an independent institution from its citizens, strived for reinforcing and making itself impenetrable against the effects of drug-related crimes.

In this regard, from the very first days of the Revolution, Hakeme Shar (clerical judge), and later the legislators, maximally criminalized the drug crimes, using the open-ended and all-embracing fiqh-based term of Efsadfel-Arz (lit. "the act of spreading corruption on the earth"). By adopting a patriarchal attitude, they resort to over criminalization, and some drug offenders were sentenced to death, charged with Efsad-fel-Arz. Despite there being no sign of such designation in the previous law, it signifies in the Shia jurisdiction or Fiqh any behavior which may lead, if left unleashed, to the annihilation of the society and social life and of the Islamic system. ${ }^{39}$ Although Sharia does not explicitly designate drug traffickers as "corrupt," the authorities regarded-on account of the views of some jurisprudentsthe spread of the adverse effects thereof as the criteria making it eligible to charge offenders with Efsad-fel-Arz and sentence them to death. On that day, the preservation of the newly founded society was such an important goal that the rules of Sharia were interpreted so extensively.

Durkheim described this condition by the power of the selfinterpretation of religion. As he said, a man who obeyed his God and

\footnotetext{
${ }^{37}$ Patrick Baron Delvin, The Enforcement of Morals, Oxford: Oxford University Press,1965,7.

${ }^{38}$ Hans J. Eysenck and Gisli H. Gudjonsson, The Causes and Cures of Criminality, New York: Springer, 1989,144.

${ }^{39}$ Mohsen Kadivar, Hagh-al-Nas, 2nd ed., Tehran: Kavir, 2008, 247.
} 
aimed to preserve the sacred society thinks that God is with him. He goes to the world with a kind of self-confidence and a feeling of increased energy in himself. ${ }^{40}$ An expanded interpretation of Sharia for the war on drugs was accompanied by a strong sense of God's pleasure. Although it was a feeling, society survives by the collective sentiments of its faithful, regardless of their validity. In doing so, Mohammadi Gilani, the clerical judge of the Revolutionary court in 1981, stated that the criterion for executing traffickers was the corruption caused by them in the Islamic society. ${ }^{41}$ One such law that is of great importance is the bill intensifying the punishment of the perpetrators of drug-related crimes and protective and medical actions to treat and find jobs for the addicts. The bill was passed in 1980 by the Council of the Islamic Revolution. The bill was the first in drugs case to have distanced itself from the laws enacted in the pre-revolutionary Iran, casting the net wider in handing out capital punishment. As Mohammadi Gilani stated, this bill "determines the items which cause Efsad-fel-Arz in the Islamic state and helps the clerical judge for determining death sentences." ${ }^{42}$

In 1982, the Supreme Judicial Council accepted the opinion of jurisprudents or fuqaha. It issued a circular announcing that if the activities of the offender in distributing and carrying drugs, and the like, caused corruption, the criminal would be regarded as Mofsed fel-Arz (lit. "criminals spreading corruption on the earth"), and the death penalty would be condign for such person. ${ }^{43}$ They interpreted specific amounts of drugs as a manifestation of corrupting the Islamic society and should be prevented. So, as Durkheim put it, religion is not just a set of facts but is the ability

${ }^{40}$ Émile Durkheim, Elementary Forms of the.. ., 211.

${ }^{41}$ Said Madani Qahfarrokhi, Drug addiction in Iran, Tehran: Sales, 2011,231.

${ }^{42}$ Said Madani Qahfarrokhi, Drug addiction in ..., 231.

${ }^{43}$ Jurisprudential Research Center, Collection of circulars of the Supreme Judicial Council from 1981-1990, Vol 1, Tehran: Deputy of Education and Research of the Judiciary, 2003. 
to act, the actions that are needed to preserve society. ${ }^{44}$ The circular has since been a gate through which capital punishment was introduced into the drugs legislation. The Supreme Judicial council's argument became the foundation for three consecutive laws on drugs. The actions taken by the authorities of the criminal justice system were rendered sacred by turning the religious matter into the dominant discourse of the war on drugs.

Pursuant to the socio-cultural changes from the early 1990s, the value system of society gradually was changing. The revolutionary religious beliefs were decreasing, and the social transition was occurring, which led to the new beliefs being replaced with the previous. Javan Jafari and Esfandiari, in brief, stated these factors were the combination of the information process expansion, extensive social relations, development of human right thoughts under the influence of internal and external norms. ${ }^{45}$ As will be seen, the religious interpretation of believers in it has changed dramatically, proving the faithful interprets religion according to the context they are in. According to the findings, although the root of harsh criminal reaction to drug crimes should be traced back to the early years of the Revolution, during the time this institution declined and needed to change based on the transformation of collective sentiments. As Durkheim believed regarding the French Revolution, "nowhere has society's ability to make itself a god or to create gods been more in evidence than during the first years of the revolution." ${ }^{46}$ As regards the Iranian society, the criteria of corruption would have changed with the development of the values of the individual conscience after going through fervid revolutionary conditions. So, although "society is to its members

\footnotetext{
${ }^{44}$ Émile Durkheim, Elementary Forms of the.. ., 419.

${ }^{45}$ Abdolreza Javan Jafari Bojnordi and Mohammad Saleh Esfandiari Bahraseman, "Sociological approach on the changes of the death penalty to Drug Criminals", Journal of Criminal Law Research, Volume 7, Number 25 (2019),125-157.

${ }^{46}$ Émile Durkheim, Elementary Forms of the.. ., 215.
} 
is what a god to its faithful... it pursues ends that are also specifically its own, but because it can achieve those ends only by working through us, it categorically demands our cooperation." 47 Society, therefore, defines the individual and the individual's demand as being intertwined with the life of the society. As a result, the legal system is supposed to revise the law according to the new condition of society.

So, although the administration of penal practices is today a monopoly of the modern states, much more population support and valorization determine which state punishment should be exercised. ${ }^{48}$ As the early years of the Islamic Revolution passed, several factors reduce the shared values about the sanctity of harsh reactions toward some drug offenders. The most significant of which was the international pressure for decreasing the number of death penalty sentences; doubt, shed by Islam scholars, on the religious nature of the death penalty for the underlings; and the impertinence of rationalizing the action in the guise of religion. For instance, Borhani criticizes surviving society through the extensive interpretation of religion. He postulated such a high rate of the death penalty could not be thought of as following from clinging to the law and implementation of Sharia, shifting the burden onto the holy law-giver. ${ }^{49}$

Although Iranian society denounces those dealing in small amounts of drugs, it does not consider them, compared to the first years of the Revolution, as those corrupting society. In fieldwork research, for instance, Hojjati asked the participants if they were lawmakers, which punishment, including the death penalty, imprisonment, fining, and other ones, they

\footnotetext{
${ }^{47}$ Émile Durkheim, Elementary Forms of the.. ., 208.

${ }^{48}$ David Garland, Punishment and Modern Society: A Study in Social Theory, Chicago: University of Chicago Press, 1990, 32.

${ }^{49}$ Mohsen Borhani, "Efsad-fel-Arz: Conceptual Ambiguity, Practical Repercussion (Evaluation of Islamic Criminal Law Article 286)", University of Tehran Criminal Law Studies, Volume 2, Number 3 (2015),19-44.
} 
would select. A percentage of $79.8 \%$ and $92 \%$ of the interviewees believed that the wholesale traffickers with the criminal record and the drug gang leaders, respectively, deserved capital punishment. Only $24.9 \%$ and $36.3 \%$, respectively, alleged that fledgling retailers traffickers and fledgling wholesale traffickers deserved the death penalty. The transformation of collective consciousness sentiments towards the corruption emanated from retailors could be sought in the reduction of the sacredness of social values. As Durkheim put it, these unanimous feelings are not a mere illusion ${ }^{50}$ and reflect the changes in previous sacred values. Ghasemi fieldwork results indicate that $86 \%$ and $85 \%$ of respondents-female and male, respectively-totally agreed with the necessity to revise the criminal laws deduced from the sharia law to fit the new requirements of the society. Moreover, many judges agreed with this statement. ${ }^{51}$

As the aforementioned pieces of evidence make evident, there is no human society that does not need to retain and stabilize the collective feelings and values that make up its unity and character in specific periods. If we look from Durkheim's lenses, it is not possible unless individuals get closer to each other, to reaffirm and consolidate their collective feelings together. ${ }^{52}$ He had again and again acknowledged human emotions intensify when they repeatedly expressed by individuals. In this case, they prepare the grounds of emerging new shared values. In this regard, as a part of the legal culture of the society, judges initiated to resist the law during those years and institutionalize new values. For instance, the number of criminals sentenced to death between 1988 and 1997 was 50,000-odd, of which $45.5 \%$ on average were approved, and the rest were

\footnotetext{
${ }^{50}$ Émile Durkheim, Elementary Forms of the.. ., 420.

${ }^{51}$ Ghasem Ghasemi, "Criminal Punishment in Islamic Societies: Empirical Study of Attitudes to Criminal Sentencing in Iran”, European Journal on Criminal Policy and Research, Volume 15, Number 1 (2009), 159-180.

${ }^{52}$ Émile Durkheim, Elementary Forms of the.. ., 429.
} 
rejected. ${ }^{53}$ Moreover, of 12,500 cases were related to drugs in recent years. Furthermore, 2,000 involved death penalty sentences for the defendants, which constitutes only $9 \%$ of all cases. Twelve percent of them were executed, and the rest were either discharged, or their cases were rejected on account of the Supreme Court's realistic outlook. ${ }^{54}$ So, when collective consciousness reaches a certain degree of intensity, it provides the ground for the awakening of new religious thoughts and, as a result, changes the condition. Judges' verdicts express their opposition in line with people.

The transformation of socially sacred values in the various classes of the society entails mapping the laws onto the novel viewpoints of the majority. Because, as Durkheim believes, "we do not condemn it [wrongdoing] because it is a crime, but it is a crime because we condemn it." ${ }^{55}$ Here, it is down to the society, which is the stable moral character above and beyond transient generations, to transfer and reify these values in the form of laws. Here the fundamental epistemological statements in Durkheim's sociology of law and religion are evident. Fighting against drugs by applying penal practices is rooted in shared moral values of collective consciousness. They are institutions built by human beings and rest on cultural relativity and take a variety of forms depending on the time, place, and cultural milieu in which they are embedded. So their changes following the changes of shared morals values are inevitable..$^{56}$ Otherwise, society would be disintegrated.

To increase the faith of believers to society or just to keep it, the shariabased institutions of drugs should reconstruct themselves along with

${ }^{53}$ Fatemeh Ghannad, "Proportionality between Illicit Drug-related Crimes and Penalties in the Iranian Legal System”, in Judiciary of the Islamic Republic of Iran (ed.), Scientific-Applied International Seminar on Different Aspects of Criminal Policy vis-a-vis Narcotic Drugs, Tehran: Judiciary of the Islamic Republic of Iran, 2000: 199-246.

${ }^{54}$ Masoud Kazemi, "The effect of the death penalty in the deterrence of commitment of narcotic and psychotropic crimes”, Social Health and Addiction, Volume 1, Number 4 (2015), $101-118$.

${ }^{55}$ Émile Durkheim, The Division of ..., 40.

${ }^{56}$ Roger Cotterrell, The Sociology of Law: An Introduction, London: Butterworth, 1984, 23. 
the new sacred values of the collective consciousness. Hence, religion is supposed to transform itself instead of disappearing. ${ }^{57}$ In this regard, the main reason behind altering the previous strict provisions was said to have generated sympathy in society. The legislative body distinguished between the wholesaler and retailer drug dealers to comply with the new sacred values. Unlike the early years of the Revolution, "small fishes" were not supposed as the enemy of the Islamic society. Citing Koranic verses, legislators deemed saving human lives important as stressed in Islam, demanding the removal of the death penalty as soon as possible. They stated, "blood is of great importance in Islam [...]. The immediacy rises from the fact that if the law is passed, many cases of the death penalty will turn into jail sentences [...]. Is there anything more important than human life?" ${ }^{8}$ Now they argued that the Islamic system could be maintained by executing "Big fishes" - not retailers. ${ }^{59}$ So, the interpretation of religious values changed dramatically and adapted to the new condition of society. Moreover, the drug laws had to be modified to target the roots-that is, the agents and gang leaders-not the retailers. ${ }^{60}$ It is the senior traffickers that wage war against security forces ${ }^{61}$ and imperil the entirety of the Islamic system.

This state of doubt and ambiguity about the sacred values of the society could not last forever. During the years, Iran's post-revolution society once again has been experiencing the moments of creative effervescence in which new ideas of Islam emerged. Society needs to obey the new shared values to survive and prevent its disintegration. So, the development of penal practices

\footnotetext{
${ }^{57}$ Émile Durkheim, Elementary Forms of the.. ., 432.

${ }^{58}$ Rooznamehrasmi, Details of the negotiations of forty-seventh session of the Islamic Consultative Assembly,2016, Retrieved on July 10, 2020 at: www.rooznamehrasmi.ir/Files/ Laws/95.09.03_47__95.10.02.pdf.

${ }^{59}$ Tasnimnews, "Mohammad Javad Larijani" ...

${ }^{60}$ Rooznamehrasmi, "Details of the negotiations" ...

${ }^{61}$ Rooznamehrasmi, "Details of the negotiations" ...
} 
is related to the changes of collective sentiments and beliefs that take place in the course of the evolution of the societies and social institutions. ${ }^{62}$ Three decades after the Revolution, the plan for reducing the number of the death penalty for drug crimes was ratified by 75 percent of the MPs.

Religious readings of the death penalty in the appending of an article to the law concerning drug control enacted in October 2017 are harbingers of development in the issue. Discourse analysis of the MPs negotiations is indicative of the fact that the most crucial reason they cited for distinguishing between big fishes and small fishes was that the former would not pose a threat to the foundations of the Islamic system. They, therefore, mentioned the objective features of the threat like being armed, organized, or being the head of a criminal group, financial support, and criminal record in Paragraphs A to D of Article 45 of the law concerning drug control amended in 2017. Although the new law still deemed the number of drugs confiscated as one of the criteria for the corruption of the society, it lay aside the amount regarded as deserving to be punished for Efsad-fel-Arz, highlighting the incapability of the underlings to put the Islamic society in danger. Thus, the previously "unsacred," which topped the criminalization list, and for which the harshest punishment was considered now is less abominable, and it entailed less repression. Durkheim persistently describes these changes as the conflict of ideals. The ideal sacred values of yesterday conflicted with the new social condition; thus, new ideals are replaced.

\section{Differential proceeding}

Durkheim asserts that all religions contain a set of complex rites, both positive and negative. ${ }^{63}$ Positive rites refer to the public ceremonies, which

\footnotetext{
${ }^{62}$ Ian Marsh, et al., Crime and Criminal Justice, London, New York: Routledge, 2011, 257.

${ }^{63}$ Émile Durkheim, Elementary Forms of the ..., 303.
} 
are held to appreciate the collective values through public gatherings. ${ }^{64}$ The negative ones, on the other hand, refer to the taboos, which prevent the faithful from "unsanctioned mixture or contact and prevent either domain from encroaching on other." ${ }^{\prime 5}$ He thinks both types are necessary for protecting socially sacred values. From his viewpoint of punishment and social solidarity theory, heavy punishments and opting for negative rites when it comes to crimes-in our case, differential procedures-are positively correlated with the sacredness of violated values. Because not all values are equally sacred, and they are accorded variable sacredness given their character, function the historical and geographical context in which they figure. Considered from a Durkheimian perspective, therefore, the differential system of Revolutionary Courts is supposed as negative rites to protect the extremely sacred value of maintaining the Islamic society.

The rationale of establishing Revolutionary Courts is a testimony to what we expounded above. These courts were found to put on trial the authorities of the previous regime (i.e., Pahlavi regime, and antirevolutionary criminals). Drug offenders were considered dangerous for the Islamic society, as were the Pahlavi-era authorities. As Javan Jafari and Esfandiari argued, in the restive milieu of Revolution, there was no difference between drug traffickers and enthusiastic followers of the previous regime in that both sought to disintegrate the newly-established Islamic society. ${ }^{66}$ Drug criminals try to undermine the foundation of Islamic society/Islam. So, they differ from ordinary criminals and required to be tried differentially. The dominance of judicial rules attributed to God in the criminal war on drugs and the fact that these crimes target the Islamic society/Islam constituted the main reason for opting for such

\footnotetext{
${ }^{64}$ Émile Durkheim, Elementary Forms of the ..., 330.

${ }^{65}$ Émile Durkheim, Elementary Forms of the ..., 330.

${ }^{66}$ Abdolreza Javan Jafari Bojnordi and Mohammad Saleh Esfandiari Bahraseman, "Sociological approach on"...
} 
differential procedures. The drug offenders considered enemies of Islamic society/Islam and tried alongside criminals with security charges like muhāriba or "enmity against God" and those insulting Islamic signs or the leader. Allocating special courts to the drug crimes, thus, stems from the greater conviction awaiting the violation of the sacred value: the survival of Islamic society.

Another manifestation of the hard function of religion in these courts was the temporary requirement for the cases to be heard by the judges of the sharia court. In the early years of the Revolution, sharia judges were supposed to hear and decide criminal cases falling under the jurisdiction of the Revolutionary Courts. As Max Weber puts it, "Kadi-justice" ${ }^{67}$ was ruled in these courts. "Kadi-justice" refers to the judge's deduction of Islam's laws and his matching the subject matter onto the figh. It is the necessary and sufficient conditions for issuing a judgment; the judge does not need to cite the text of the law here. It is inherently individualistic and substantive. ${ }^{68}$ Assigning Ayatollah Khalkhali instantiated the first case of "Kadi-justice" in post-revolutionary Iran. Khalkhali was assigned by the decree of Ayatollah Khomeini as the first sharia court judge and was required by the leader to issue rulings in compliance with " sharia criteria." ${ }^{9}$

After a brief time, the fundamental role of sharia court judges in deciding criminal cases was highlighted once more by the regulations of the Islamic Revolutionary Court 1979. The regulation specified that the Islamic Revolutionary Court be composed of three main members plus two alternate members and that the sharia court judge presides the court. The three members included a sharia court judge proposed by the Council of Islamic Revolution and ratified by Ayatollah Khomeini, a

\footnotetext{
${ }^{67}$ Max Weber, From Max Weber: Essays in Sociology, London: Routledge, 2007, 219.

${ }^{68}$ Max Weber, From Max Weber ..., 219.

${ }^{69}$ Seyyed Ruhollah Khomeini, Sahifeh-ye Imam, Vol 6, Tehran: Institute of Organizing and Publishing Imam Khomeini's Works, 1979, 215.
} 
judge from the Ministry of Justice selected by the sharia court judge, and a person trusted by people and cognizant of the requirements of the Islamic Revolution, assigned by the Council of Islamic Revolution or, otherwise, by a representative the Council appoints for this purpose. Over time and with modifications in the criminal procedural laws, the necessity for the issuance of rulings by the sharia court judges was obviated due to sharia criterion, and the judges-of sharia courts or otherwise-were asked to issue rulings based on the objective criteria of the law.

\section{Conclusion}

This paper supports the claim of Durkheim that sacredness is highly contagious. The sanctity of the Islamic society would cause the sacredness of whatever society needs for survival. Instances of such contagion in the post-revolutionary Iran are the devilishness attributed to the drug offenders and the state's efforts to neutralize them. After the Revolution, readings subscribing to the evil/martyr dichotomy that symbolized drug traffickers and the forces involved in the war on drugs, respectively, had the upper hand in Iran. Iranian religious leaders have always assumed the drug crimes as the enemies of religion and faith, of the Iranian citizens. The people also intensified the dichotomy. The post-revisionary legislator recognizes drug traffickers based on the religious interpretation, as the elements "corrupting" the Islamic society. Moreover, the survival of the Islamic society is of such gravity for the legislators that drug offenders are tried in specialized, revolutionary courts on a par with those desecrating the sacred matters of the country.

The Islamic society was for long seeking to protect its foundations by employing preternatural ways (such as specialized legislative bodies such as the Council of Islamic Revolution, and Expediency Assembly). Following the socio-cultural changes during the 1990s, the shared morals about the 
sacredness of current preventing measures changed. These oppositions were reflected in opinion polls and the judge's verdicts. Thus, as Durkheim argued, legal rules are dynamic realities and approximately progress in keeping with the new shared moral values. In this regard, society, which is alive and active within us, became conscious of itself and established its existence by regarding these new sacred collective thoughts and feelings represented by its followers. In line with the public demand, drug law has been revised.

\section{Bibliography}

Abbasi, Atefeh and Rangchitehrani, Atieh, "A new Opinion at issuance and performance Hudud on children and adolescents", Islamic Law Research Journal, Volume 21, Number 5 (2020): 151-176.

Abdul Hakim, Sudarnoto, "Islam and government: an analytical review on Khumayni's Kashf al-Asrār and Wilāyat al-Fāqih", Indonesian Journal of Islam and Muslim Societies, Volume 8, Number 1 (2018): 147-171.

Borhani, Mohsen, "Efsad-fel-Arz: Conceptual Ambiguity, Practical Repercussion (Evaluation of Islamic Criminal Law Article 286)", University of Tehran Criminal Law Studies, Volume 2, Number 3 (2015):19-44.

Cotterrell, Roger. The Sociology of Law: An Introduction. London: Butterworth, 1984.

Delvin, Patrick Baron. The Enforcement of Morals. Oxford: Oxford University Press, 1965.

Duguit, Léon. Les transformations du droit public. Paris: Armand Colin,1999.

Durkheim, Émile. The Division of Labour in Society. London: Palgrave MacMillan Ltd, 1984.

Durkheim, Émile. Elementary Forms of the Religious Life. New York: Free Press, 1995.

Durkheim, Émile. Suicide: A study in Sociology. London: Taylor \& Francis, 2005.

Ehrlich, Eugene and Ziegert, Klaus A. Fundamental Principles of the Sociology of Law. New York: Transaction Publications, 2001.

Eysenck, Hans J. and Gudjonsson, Gisli H. The Causes and Cures of Criminality. New York: Springer, 1989.

Farsi, Khamenei, "Students meet with the Leader of the Revolution during the training week", 1991, Retrieved on July 10, 2020 at: https://farsi.khamenei.ir/newscontent?id=547. 
Farsi, Khamenei, "Statements on the occasion of the 19th anniversary of the death of Imam Khomeini", 2008, Retrieved on July 10, 2020 at: https://farsi. khamenei.ir/speech-content?id=3463.

Farsi, Khamene,. "Message to the Great Hajj Congress", 2009, Retrieved on July 10, 2020 at: http://farsi.khamenei.ir/message-content?id=8436.

Foucault, Michel. Discipline and Punish. London: Penguin Books,1995.

Garland, David. Punishment and Modern Society: A Study in Social Theory. Chicago: University of Chicago Press, 1990.

Garland, David, "Sociological Perspectives on Punishment", Crime and Justice, Volume 14 (1991):115-165.

Ghannad, Fatemeh, "Proportionality between Illicit Drug-related Crimes and Penalties in the Iranian Legal System”, in Judiciary of the Islamic Republic of Iran (ed.). Scientific-Applied International Seminar on Different Aspects of Criminal Policy vis-a-vis Narcotic Drugs. Tehran: Judiciary of the Islamic Republic of Iran, 2000: 199-246.

Ghasemi, Ghasem, "Criminal Punishment in Islamic Societies: Empirical Study of Attitudes to Criminal Sentencing in Iran”, European Journal on Criminal Policy and Research, Volume 15, Number 1 (2009): 159-180.

Ghodsi, Seyyed Ebrahim and Porzarrin, Ali, "Critical analysis of article 637 of Islamic criminal law", Journal of Humanities and Social Sciences, Volume 3, Number 9 (2003): 183-211.

Hamilton, Malcolm. The Sociology of Religion: Theoretical and comparative perspectives, London, New York: Routledge, 2001.

Hojjati, Soodeh. Tehran Citizen's opinions about war on drugs and drug addiction. Tehran: Secretariat of war on drugs office, 2003.

IRNA. “70\% of prisoners' crimes are related to drugs”, 2018, Retrieved on July 10, 2020 at: www.irna.ir/news/83097023/.

Javan Jafari Bojnordi, Abdolreza and Esfandiari Bahraseman, Mohammad Saleh, "Sociological approach on the changes of the death penalty to Drug Criminals", Journal of Criminal Law Research, Volume 7, Number 25 (2019):125-157.

Jurisprudential Research Center. Collection of circulars of the Supreme Judicial Council from 1981-1990, Vol 1. Tehran: Deputy of Education and Research of the Judiciary, 2003.

Kadivar, Mohsen. Hagh-al-Nas. 2nd ed. Tehran: Kavir, 2008.

Kazemi, Masoud, "The effect of the death penalty in the deterrence of commitment of narcotic and psychotropic crimes", Social Health and Addiction, Volume 1, Number 4 (2015): 101-118. 
Khomeini, Seyyed Ruhollah. Sahifeh-ye Imam. Vol 5. Tehran: Institute of Organizing and Publishing Imam Khomeini's Works, 1979.

Khomeini, Seyyed Ruhollah. Sahifeh-ye Imam. Vol 6. Tehran: Institute of Organizing and Publishing Imam Khomeini's Works, 1979.

Khomeini, Seyyed Ruhollah. Sahifeh-ye Imam. Vol 20. Tehran: Institute of Organizing and Publishing Imam Khomeini's Works, 1979.

Khomeini, Seyyed Ruhollah. Sahifeh-ye Imam. Vol 21. Tehran: Institute of

Organizing and Publishing Imam Khomeini's Works, 2010.

Marsh, Ian, et al., Crime and Criminal Justice. London, New York: Routledge, 2011. Menski, Werner. Hindu Law: Beyond Tradition and Modernity. New Delhi: Oxford University Press, 2008.

Qahfarrokhi, Said Madani. Drug addiction in Iran. Tehran: Sales, 2011.

Rooznamehrasmi, "Details of the negotiations of forty-seventh session of the Islamic

Consultative Assembly", 2016, Retrieved on July 10, 2020 at: www. rooznamehrasmi.ir/Files/Laws/95.09.03_47__95.10.02.pdf.

Serverin, Évelyne. Sociologie du Droit. Paris: La Découverte, Repères, 2000.

Shapiro, Scott J. Legality. Cambridge: The Belknap Press of Harvard University Press, 2011.

Shah, Prakash. Legal Pluralism in Conflict: Coping with Cultural Diversity in Law. London: Routledge, 2005.

Standen, Jeffrey, "Critical Legal Studies as an Anti-Positivist Phenomenon", Virginia Law Review, Volume 72, Number 5 (1986): 983-998.

Tavakoli, Fatemeh, et al., "Religious Foundations and the Principles of Criminalization of Blasphemy and the Challenges", Criminal Law Research, Volume 6, Number 2 (2015): 49-74.

Tasnimnews, "Mohammad Javad Larijani: 93\% of executions in Iran are related to drugs

/ The death penalty should be limited to drug traffickers", 2016, Retrieved on July 10, 2020 at www.tn.ai/1207613.

Tasnimnews, "Statistics of martyrs of 40 years of war on drugs+separate tables", 2019, Retrieved on July 10, 2020 at: www.tn.ai/2126272.

Timasheff, Nicholas Sergeyevitch. An Introduction to the Sociology of Law. New Brunswick: Transaction Publishers, 2002.

Weber, Max. From Max Weber: Essays in Sociology. London: Routledge, 2007.

Yilmaz, Ihsan. Muslim Laws, Politics and Society in Modern Nation States: Dynamic Legal Pluralisms in England, Turkey and Pakistan. Aldershot: Ashgate, 2005. 